(c) American Dairy Science Association, 2004.

\title{
Effects of Somatic Cell Count and Stage of Lactation on the Plasmin Activity and Cheese-Making Properties of Ewe Milk
}

\author{
M. Albenzio, ${ }^{1}$ M. Caroprese, ${ }^{1}$ A. Santillo, ${ }^{1}$ R. Marino,,${ }^{1}$ L. Taibi, ${ }^{2}$ and A. Sevi ${ }^{1}$ \\ ${ }^{1}$ Dipartimento PRIME, Università di Foggia, Italy \\ ${ }^{2}$ Istituto Sperimentale per la Zootecnia. Sezione Operativa di Segezia-Foggia, Italy
}

\begin{abstract}
The experiment was conducted from March to July 2002 using 5 intensively managed flocks of Southern Italy. In each flock, 2 groups of 50 ewes were created. The groups were designated LSCC (low somatic cell count [SCC]) when their milk SCC was lower than $500,000 / \mathrm{mL}$ and HSCC (high SCC) when their milk SCC was higher than $1,000,000 / \mathrm{mL}$. Bulk milk and whey samples were analyzed for fat, total protein, lactose, casein, and whey protein contents. Renneting properties of milk were also determined. Moisture, $\mathrm{NaCl}$, and nitrogen fractions were determined in fresh cheese curds. In addition, plasmin (PL) and plasminogen (PG) activities in milk and cheese were monitored. The proteolytic activity of plasmin by urea-polyacrylamide gel electrophoresis and the white blood cell (WBC) differentials were determined. The HSCC resulted in higher $\mathrm{pH}$ values in milk and in higher moisture and lower fat contents in fresh cheese curds. Moreover, a lower recovery of fat and whey proteins was obtained from the HSCC than from the LSCC raw milk. The crude protein and casein contents were higher in the HSCC than in the LSCC curds during early and midlactation; an opposite trend was observed in late lactation. Plasmin and PG activities underwent more marked fluctuations in the LSCC than in the HSCC curds through lactation. The results of this experiment demonstrate that the PL activity in ewe milk is markedly influenced by the SCC, although SCC is not the only parameter for predicting PL and PG evolution in ewe milk. The LSCC milk resulted in a higher proteolytic potential of Canestrato pugliese cheese curds.
\end{abstract}

(Key words: plasmin activity, proteolysis, somatic cell count, stage of lactation)

Abbreviation key: HSCC = high SCC, LSCC = low SCC, $\mathbf{N C N}=$ noncasein nitrogen, $\mathbf{P G}=$ plasminogen, $\mathbf{P L}=$ plasmin, $\mathbf{W B C}=$ white blood cells.

Received September 15, 2003.

Accepted November 4, 2003.

Corresponding author: M. Albenzio, e-mail: m.albenzio@unifg.it.

\section{INTRODUCTION}

Milk SCC is a widely used marker for both udder health and milk quality (O'Brien et al., 2001). The SCC in milk varies because of a number of external factors such as mastitis, stage of lactation, season, milk yield, and number of lactations (Bastian and Brown, 1996; Albenzio et al., 2002; Sevi et al., 2001). It has been shown that an increase in milk SCC can cause an increase in the amount of proteolytic activity and can reduce the yield and quality of cheese (Ali et al., 1980; Grandison and Ford, 1986; Verdi and Barbano, 1991). Kelly et al. (2000) found that an elevated SCC can alter the protein fractions distribution; decrease casein and lactose levels in milk; increase rennet clotting time, cheese moisture, and losses of fat and proteins in whey, and reduce curd firmness and cheese yielding.

Kelly and McSweeney (2002) reported that somatic cells, the principal physiological function of which is to defend the udder from infections, contain lysosomes that release active proteolytic enzymes (i.e., elastase, collagenase, and cathepsins). Plasmin plays the main role among the proteolytic enzymes in milk; plasmin can rapidly cleave both $\beta$-casein into $\gamma$-casein and smaller polypeptides (Auldist et al., 1996) and $\alpha$ s1- and $\alpha$ s2-CN (Le Bars and Gripon, 1993; McSweeney et al., 1993). The increase in plasmin (PL) activity is the main factor responsible for impaired coagulation features and casein degradation in milk (Lucey, 1996; Srinivasan and Lucey, 2002) and leads to a reduction in cheese yield and to changes in functionality of milk protein with regard to milk coagulation (Zachos et al., 1992).

Changes in the yield and quality of ewe milk through lactation are influenced by both seasonal and physiological factors (Sevi et al., 2002). Bastian et al. (1991) suggested that the flow of enzyme from blood into milk increases in early lactation and remains constant thereafter, even though greater activation of plasminogen (PG) and a higher PL activity occurs toward the end of lactation (Bastian and Brown, 1996). Richardson (1983) found that the increase in PL activity is due to more PL entering the mammary gland rather than to increased levels of PG activators. On the contrary, Zachos et al. (1992) showed no effect of stage of lactation on PG activator levels. 
Poor coagulating properties are often observed with late lactation milk (Grufferty and Fox, 1988); such milk often contains higher concentrations of proteose peptones (Phelan et al., 1982), as $\gamma$-CN and other caseins breakdown products in mid-lactation milk (Okigbo et al., 1985). This seems to suggest that increased PL activity is responsible for the poor coagulating properties of late lactation milk (O'Keeffe et al., 1982).

The aim of this study was to determine the effects of SCC and stage of lactation on the enzymatic activity of ewe milk, curd composition, and cheese-making properties.

\section{MATERIALS AND METHODS}

\section{Experimental Design and Animal Management}

The experiment was conducted from March to July 2002 using 5 intensively managed flocks of Comisana ewes located in Southern Italy. In all flocks, sheep were housed on straw litter in prefabricated buildings and were given hay and concentrates during the winter months. During the spring season and until the beginning of summer, the ewes grazed and were supplemented with hay and concentrates in the trough. Because of herbage scarcity, the ewes only received hay and concentrate in the trough during mid summer. The ewes were milked twice daily in parlors using pipeline milking machines. In each flock, 2 groups of 50 ewes were selected on the basis of milk SCC recorded during the previous lactations the month before the commencement of the experiment. Groups were LSCC (low SCC) when the SCC content was lower than $500,000 / \mathrm{mL}$ and HSCC (high SCC) when the SCC content was higher than $1,000,000 / \mathrm{mL}$. Averages of milk SCC were (X \pm SE) $245 \pm 32,234 \pm 43$, and $248 \pm 36$ in the LSCC groups and $2051 \pm 104,1834 \pm 112$, and $2241 \pm 116$ cells $/ \mathrm{mL}$ in the HSCC groups, respectively, during early, mid, and late lactation. Before starting the trial and before each sampling cycle, the selected ewes were carefully examined by veterinarians to detect the presence or confirm the absence of signs of clinical mastitis, such as fever, pain, or gland swelling. A small quantity of milk was checked visually for signs of mastitis. Ewes showing any sign of clinical mastitis were excluded from the sampling cycle. However, microbiological analysis on milk was not carried out, so the existence of subclinical mastitis cannot be excluded in the HSCC group. For each flock, three sampling cycles were performed during early, mid, and late lactation (less than $70 \mathrm{~d}$, from 110 to $130 \mathrm{~d}$, and more than 160 in lactation, respectively). For each sampling cycle, samples were collected in triplicate from the milk of 6 consecutive milkings. In each flock, the ewes with a milk SCC exceeding or below the appointed thresholds during the sampling cycle the day before were excluded from the experimental groups; the number of ewes per group was never less than 42 .

\section{Sampling and Analyses of Milk, Whey, and Cheese}

A total of 270 milk samples were collected and analyzed for fat, total protein, and lactose (Milko Scan 133B; Foss Electric, DK-3400 Hillerød, Denmark). Total nitrogen, noncasein nitrogen (NCN), and NPN were determined by standard procedures using the Kjeldahl method (International Dairy Federation, 1993). Casein nitrogen was calculated as the difference between total protein and NCN; whey protein was calculated as the difference between NCN and NPN. All nitrogen results were expressed as protein equivalent using a conversion factor of 6.38. Somatic cell count was determined using a Fossomatic 90 (Foss Electric) according to the International Dairy Federation (1995) standard; white blood cell (WBC) differential was determined by means of direct microscopic count in milk smears stained with May-Grünwald-Giemsa. Renneting characteristics (clotting time, rate of clot formation, and clot firmness after $30 \mathrm{~min}$ ) were measured using a Foss Electric Formagraph and the method of Zannoni and Annibaldi (1981).

The pool milk collected during each sampling cycle was stored under refrigeration at $4^{\circ} \mathrm{C}$ and then processed for Canestrato pugliese cheese according to the traditional protocol reported by Albenzio et al. (2001). Three cheeses were manufactured from the HSCC and the LSCC milk obtained in each flock. In fresh cheese curds, the moisture content was determined according to the International Dairy Federation (1970) standard after $24 \mathrm{~h}$ of aging. Total nitrogen and $\mathrm{pH} 4.6$-soluble $\mathrm{N}$ were determined as described by Gripon et al. (1975); total nitrogen minus $\mathrm{pH} 4.6$-soluble $\mathrm{N}$ yielded casein nitrogen. The fat content was determined by the Soxhlet method using petroleum ether.

Milk and cheese $\mathrm{pH}$ and calcium content were determined according to International Dairy Federation (1989; 1992) standards.

Whey samples were analyzed for fat, lactose, total protein, casein, and whey protein contents as for milk samples.

\section{Determination of PL and PG Activities in Milk and Fresh Cheese Curd}

Plasmin and PG activities in milk were determined according to the method of Baldi et al. (1996); the dissociation of PL and PG from casein micelles was obtained by incubation of skim milk with $50 \mathrm{~m} M$ of $\varepsilon$-aminocaproic acid for $2 \mathrm{~h}$ at room temperature as described by Korycka-Dahl et al. (1983). The reaction mixture was 
of $250 \mu \mathrm{L}$ of $0.1 M$ Tris-HCl buffer ( $\mathrm{pH} 7.4$ ), $0.6 \mathrm{mM}$ Val-Leu-Lys-p-nitroanilide (V7127; Sigma Chemical Co., St. Louis, MO), 30 plough units $(2.5 \mu \mathrm{L})$ of urokinase (U0633; Sigma Chemical Co.), and $30 \mu \mathrm{L}$ of milk serum. Plasmin activity was measured in the same reaction mixture without added urokinase. Plasminogenderived activity was the difference. A similar reaction mixture without sample was used as a control. The reaction mixture was incubated at $37^{\circ} \mathrm{C}$ for $3 \mathrm{~h}$, and $\mathrm{A}_{405}$ was measured at 30-min intervals with a microtiter plate reader (Anthos 2020 version 1.0; Diessechem, Milano-Italy). One unit of PL or PG activity was defined as the amount of the enzyme that produces a change in absorbance at $405 \mathrm{~nm}$ of 0.1 in $60 \mathrm{~min}$.

Plasmin and PG activities in fresh cheese curd were determine according to the method of Richardson and Pearce (1981) modified accordingly: on the grated cheese $(5 \mathrm{~g})$ dispersed in $20 \mathrm{~mL} 0.4 \mathrm{M}$-sodium citrate $(\mathrm{pH} 8.5)$, after equilibration at $38^{\circ} \mathrm{C}$ for $15 \mathrm{~min}$, the mixture was homogenized in a Stomacher Lab-Blender 400 (PBI International, Milan, Italy) for $5 \mathrm{~min}$. The assay of PL and PG activities were detected as previously described for milk samples.

\section{Urea-Page of PL Activity on Na-caseinate}

To investigate the plasmin proteolytic activity, 4\% ovine Na-caseinate in a Tris-buffer ( $\mathrm{pH}$ 8.0) was used. Whole casein and sodium caseinate were prepared from a sample of ovine skim milk according to the method of Mulvihill and Fox (1977). Sodium caseinate was dissolved in 0.1 $M$ Tris-base (Sigma Chemical Co.) and sodium azide $(0.5 \%)$. Serum obtained by ultracentrifugation of skim milk $\left(27,000 \mathrm{~g} \times 20 \mathrm{~min}\right.$ at $\left.4^{\circ} \mathrm{C}\right)$ was incubated in sodium caseinate buffer from 0 to $24 \mathrm{~h}$ at $37^{\circ} \mathrm{C}$. In HSCC milk, the effects of plasmin activity on sodium caseinate were evaluated by urea-PAGE using a Protean II xi vertical slab gel unit (Bio-Rad, Watford, UK). The stacking and resolving gel system was prepared as described by Andrews (1983). The gels were stained using a modification of the method of Blakesley and Boezi (1977) with Coomassie Brillant Blue G250.

\section{Statistical Analyses}

Milk, whey, and cheese variables were processed using the GLM procedure for repeated measures (SAS, 1999). The variation caused by SCC, stage of lactation, and their interaction was tested. Replication within treatment was used as the error term. When significant effects were found (at $P<0.05$, unless otherwise noted), the Student $t$-test was used to locate significant differences between means. Farm effects were significant only a very few times, probably because of the very similar flock management adopted in the farms where the investigation was conducted. Hence, farm effects were not included in the statistical model.

\section{RESULTS}

\section{Milk Composition}

The average milk yields were $886 \pm 28 \mathrm{~g} / \mathrm{d}$ for the LSCC group and $472 \pm 37 \mathrm{~g} / \mathrm{d}$ for the HSCC (data not shown). The chemical composition of ewe milk is presented in Table 1. Crude protein content was higher in the HSCC milk than in the LSCC milk both in early $(P<0.001)$ and late $(P<0.05)$ lactation; the same trend was observed for the whey protein content during the whole lactation period. No differences were found in casein and fat contents. Regardless of milk SCC, whey protein and fat contents increased with the advancement of lactation, but lactose content decreased. The lowest CP content was found during early lactation in the LSCC milk and during midlactation in the HSCC milk. Plasmin and PG activities were affected by SCC $(P<0.001)$; PL activity was significantly higher $(P<$ 0.01) in the HSCC milk than in the LSCC milk throughout lactation (Figure 1). In contrast, PG activity was higher in the HSCC milk than in the LSCC milk $(P<$ 0.001) only during midlactation (Figure 2 ). The PG:PL ratio was lower in the HSCC milk than in the LSCC milk throughout lactation and, regardless of milk SCC, was higher in mid than in early and late lactation (data not shown). Higher $\mathrm{pH}$ values were found in the HSCC milk than in the LSCC milk $(P<0.001)$ during mid and late lactation (Table 2). The LSCC milk had a lower clotting time and a higher curd firmness compared with the HSCC milk throughout lactation $(P<0.001)$; rate of clot firming was found to be lower in the LSCC milk than in the HSCC milk during early $(P<0.01)$ and late lactation $(P<0.05)$. Clotting time decreased and rate of firming increased with the advancement of lactation in the LSCC milk; in the HSCC milk, the lowest values of both parameters were found in midlactation. Regardless of milk SCC, the highest curd firmness values were found in midlactation, and the lowest were found in late lactation.

Table 3 shows the WBC differential observed in the HSCC milk. Only macrophages significantly changed $(P<0.05)$ during lactation: the lowest values were observed in midlactation $(2.40 \%)$ and the highest were observed in late lactation (4.31\%). In the LSCC milk, the WBC differential data were judged not accurate enough because of the low cell number (Pasquinelli, 1981) and were not included in the paper.

Correlation coefficients between PL, PG, and PG:PL ratio and milk composition and coagulation characteristics are reported in Table 4. The PL and PG activities 
Table 1. Least square means ( \pm SEM) of chemical composition of ewe milk with low SCC (LSCC) and high SCC (HSCC) during lactation.

\begin{tabular}{|c|c|c|c|c|c|c|c|}
\hline & \multirow[b]{2}{*}{$\begin{array}{l}\text { Stage of } \\
\text { lactation }\end{array}$} & \multirow[b]{2}{*}{ LSCC } & \multirow[b]{2}{*}{ HSCC } & \multirow[b]{2}{*}{ SEM } & \multicolumn{3}{|c|}{ Effect } \\
\hline & & & & & $\mathrm{SCC}$ & $\begin{array}{l}\text { Stage of } \\
\text { lactation }\end{array}$ & $\begin{array}{l}\text { SCC } \times \text { stage } \\
\text { of lactation }\end{array}$ \\
\hline & & & & & & $x_{2}$ & 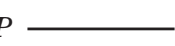 \\
\hline \multirow[t]{3}{*}{$\mathrm{CP}, \%$} & Early & $5.40^{\mathrm{a}}$ & $5.86^{\mathrm{b}}$ & & & & \\
\hline & Mid & 5.46 & 5.56 & & & & \\
\hline & Late & $5.99^{\mathrm{a}}$ & $6.27^{\mathrm{b}}$ & 0.08 & $* * *$ & $* * *$ & NS \\
\hline \multirow[t]{3}{*}{ Casein, \% } & Early & 4.12 & 4.27 & & & & \\
\hline & Mid & 3.96 & 4.03 & & & & \\
\hline & Late & 4.21 & 4.33 & 0.11 & NS & NS & NS \\
\hline \multirow[t]{3}{*}{ Whey protein, \% } & Early & $1.17^{\mathrm{a}}$ & $1.28^{\mathrm{b}}$ & & & & \\
\hline & Mid & $1.21^{\mathrm{a}}$ & $1.40^{\mathrm{b}}$ & & & & \\
\hline & Late & $1.35^{\mathrm{a}}$ & $1.51^{\mathrm{b}}$ & 0.03 & $* * *$ & $* * *$ & NS \\
\hline \multirow{3}{*}{ Fat, \% } & Early & 6.54 & 6.72 & & & & \\
\hline & Mid & 7.46 & 7.59 & & & & \\
\hline & Late & 8.61 & 8.34 & 0.21 & NS & $* * *$ & NS \\
\hline \multirow[t]{3}{*}{ Lactose, \% } & Early & $4.81^{b}$ & $4.47^{\mathrm{a}}$ & & & & \\
\hline & Mid & $4.59^{\mathrm{b}}$ & $4.08^{\mathrm{a}}$ & & & & \\
\hline & Late & $4.36^{\mathrm{b}}$ & $3.70^{\mathrm{a}}$ & 0.09 & $* * *$ & $* * *$ & $*$ \\
\hline
\end{tabular}

${ }^{\mathrm{a}, \mathrm{b}}$ Means within the same row followed by different letters differ at $P<0.05$.

$* P<0.05$.

$* * * P<0.001$

and the PG:PL ratio were not significantly correlated with casein content, rate of firming, and curd firmness. Positive correlations between PL and whey proteins $(P$ $<0.001), \log \operatorname{SCC}(P<0.001)$, and clotting time $(P<0.01)$ were found. Moreover $P G$ was positively correlated with $\log$ SCC $(P<0.01)$ and clotting time $(P<0.001)$. The PG:PL ratio was only correlated with clotting time $(P$ $<0.001)$.

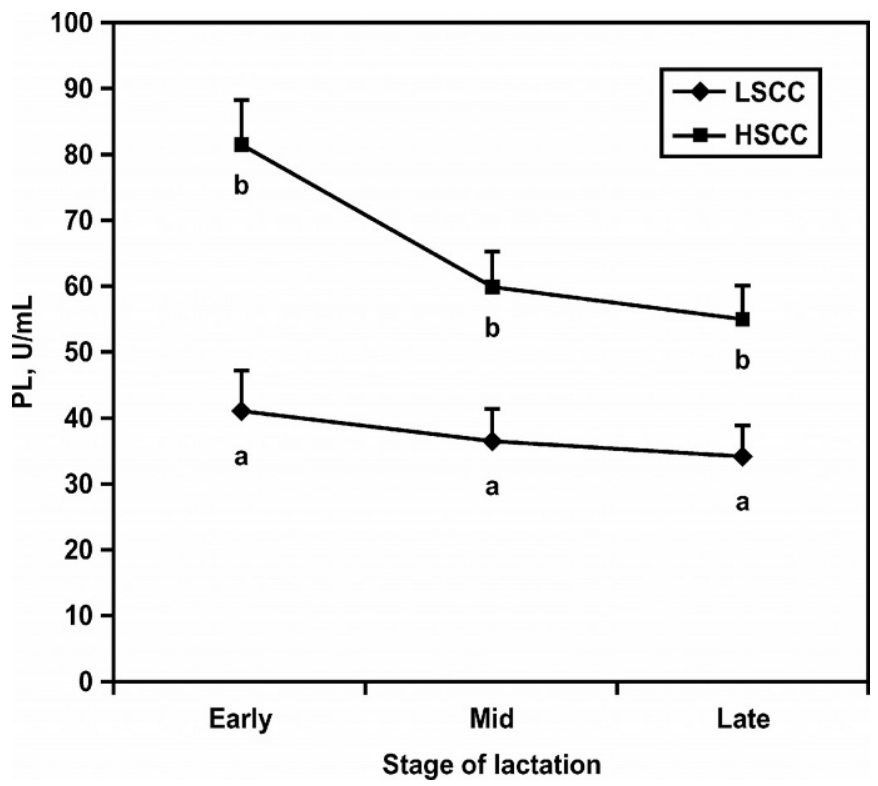

Figure 1. Plasmin (PL) activity in ewe milk with low SCC (LSCC) and high SCC (HSCC) during early, mid, and late stages of lactation. ${ }^{\mathrm{a}, \mathrm{b}}$ Means followed by different letters differ at $P<0.05$.

\section{Fresh Cheese Curd Properties and Whey Composition}

The chemical composition of fresh cheese curds $24 \mathrm{~h}$ after manufacture is reported in Table 5. In the curds obtained from early lactation milk, $\mathrm{pH}$ and calcium contents were found lower in the HSCC milk than in the LSCC milk $(P<0.001)$; an opposite trend was observed

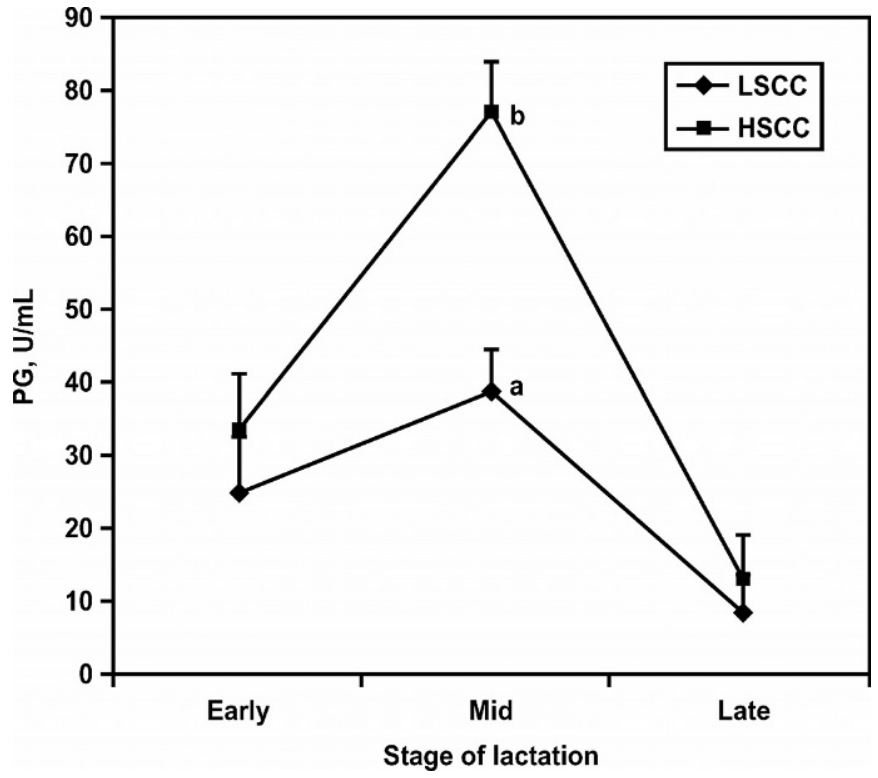

Figure 2. Plasminogen (PG) activity in ewe milk with low SCC (LSCC) and high SCC (HSCC) during early, mid, and late stages of lactation. ${ }^{\mathrm{a}, \mathrm{b}}$ Means followed by different letters differ at $P<0.05$. 
Table 2. Least square means ( \pm SEM) of renneting properties of ewe milk used for cheese making with low SCC (LSCC) and high SCC (HSCC) during lactation.

\begin{tabular}{|c|c|c|c|c|c|c|c|}
\hline & \multirow[b]{2}{*}{$\begin{array}{l}\text { Stage of } \\
\text { lactation }\end{array}$} & \multirow[b]{2}{*}{ LSCC } & \multirow[b]{2}{*}{ HSCC } & \multirow[b]{2}{*}{ SEM } & \multicolumn{3}{|c|}{ Effect } \\
\hline & & & & & SCC & $\begin{array}{l}\text { Stage of } \\
\text { lactation }\end{array}$ & $\begin{array}{l}\text { SCC } \times \text { stage } \\
\text { of lactation }\end{array}$ \\
\hline & & & & & & & $P$ \\
\hline \multirow[t]{3}{*}{$\mathrm{pH}$} & Early & 6.66 & 6.75 & & & & \\
\hline & Mid & $6.65^{\mathrm{a}}$ & $6.92^{\mathrm{b}}$ & & & & \\
\hline & Late & $6.62^{\mathrm{a}}$ & $6.93^{\mathrm{b}}$ & 0.04 & $* * *$ & NS & $* *$ \\
\hline \multirow[t]{3}{*}{ Clotting time, $\min$} & Early & $9.03^{\mathrm{a}}$ & $19.56^{\mathrm{b}}$ & & & & \\
\hline & Mid & $5.56^{\mathrm{a}}$ & $11.03^{b}$ & & & & \\
\hline & Late & $3.56^{\mathrm{a}}$ & $14.03^{\mathrm{b}}$ & 0.29 & $* * *$ & $* * *$ & $* * *$ \\
\hline \multirow[t]{3}{*}{ Rate of firming, min } & Early & $1.03^{\mathrm{a}}$ & $2.56^{\mathrm{b}}$ & & & & \\
\hline & Mid & 2.01 & 1.57 & & & & \\
\hline & Late & $2.03^{\mathrm{a}}$ & $3.03^{b}$ & 0.29 & $* *$ & $*$ & $* *$ \\
\hline \multirow[t]{3}{*}{ Curd firmness, mm } & Early & $63.03^{\mathrm{b}}$ & $52.03^{\mathrm{a}}$ & & & & \\
\hline & Mid & $65.01^{\mathrm{b}}$ & $60.11^{\mathrm{a}}$ & & & & \\
\hline & Late & $57.1^{\mathrm{b}}$ & $48.10^{\mathrm{a}}$ & 0.56 & $* * *$ & $* * *$ & $* * *$ \\
\hline
\end{tabular}

${ }^{\mathrm{a}, \mathrm{b}}$ Means within the same row followed by different letters differ at $P<0.05$.

$* P<0.05$.

$* * P<0.01$.

$* * * P<0.001$

during mid and late lactation. The moisture content was higher, and the fat content was lower, in the HSCC fresh cheese curds than in the LSCC fresh cheese curds during early and midlactation $(P<0.001)$. The $\mathrm{CP}$ and the casein contents were higher in the HSCC curds than in the LSCC curds during early and midlactation; an opposite trend was observed in late lactation. The water-soluble nitrogen fractions and proteose peptone fractions were not affected by SCC, stage of lactation, and their interaction (data not shown). Changes in PL and PG activities in fresh cheese curds are reported in Figures 3 and 4. In the LSCC group, PL activity was found higher during early and late lactation and lower in midlactation. The PG activity was similar in early lactation and was found significantly higher in the LSCC fresh cheese curds than in the HSCC fresh cheese curds during mid and late lactation. In general, PL and PG activities underwent more marked fluctuations in the LSCC curds than in the HSCC curds through lactation. In fact, in early lactation, PL activity was about
$15 \mathrm{U} / \mathrm{g}$ in the LSCC curds, dropped below $10 \mathrm{U} / \mathrm{g}$ in midlactation, and then rose again to about $25 \mathrm{U} / \mathrm{g}$ in late lactation. At the same time, PG activity passed from about $14 \mathrm{U} / \mathrm{g}$ in early lactation to over or near 25 $\mathrm{U} / \mathrm{g}$ in mid and late lactation.

The urea-PAGE of the plasmin activity $(\mathrm{pH}$ 8.0) on sodium-caseinate in the HSCC milk is presented in Figure 5. The electrophoretogram shows lower degradation products of $\beta$-CN after 0 and $24 \mathrm{~h}$ of incubation in late lactation than in early and midlactation. In contrast, $\alpha$-CN remained substantially unchanged both at 6 and $24 \mathrm{~h}$ of incubation.

The fat content in the whey from cheese making (Table 6) increased with the advancement of lactation and was higher in the HSCC group than in the LSCC group throughout the study period $(P<0.001)$. The lactose content was higher in the LSCC whey than in the HSCC whey at each sampling time, but the $\mathrm{CP}$ and whey protein contents were found higher in the HSCC group during mid and late lactation. No differences emerged

Table 3. Least square means ( \pm SEM) of white blood cell (WBC) differentials in the high SCC milk during lactation.

\begin{tabular}{lccccc}
\hline & \multicolumn{3}{c}{ Stage of lactation } & & Effect $(P)$ \\
\cline { 2 - 4 } & Early & Mid & Late & SEM & Stage of lactation \\
\hline Lymphocytes, \% & 46.53 & 41.36 & 42.12 & 3.21 & NS \\
Neutrophils, \% & 48.25 & 56.15 & 51.43 & 3.02 & NS \\
Basophils, \% & 1.14 & 1.16 & 1.58 & 0.21 & NS \\
Eosinophils, \% & 1.16 & 1.01 & 1.50 & 0.22 & NS \\
Macrophages, \% & 3.31 & $2.40^{\mathrm{a}}$ & $4.31^{\mathrm{b}}$ & 0.58 & $*$ \\
\hline
\end{tabular}

${ }^{\mathrm{a}, \mathrm{b}}$ Means within the same row followed by different letters differ at $P<0.05$.

$* P<0.05$. 
Table 4. Correlation coefficients between plasminogen activation system and some milk components and renneting parameters

\begin{tabular}{lllllrr}
\hline & Casein & $\begin{array}{l}\text { Whey } \\
\text { protein }\end{array}$ & $\begin{array}{l}\text { Log } \\
\text { SCC }\end{array}$ & $\begin{array}{l}\text { Clotting } \\
\text { time }\end{array}$ & $\begin{array}{r}\text { Rate of } \\
\text { firming }\end{array}$ & $\begin{array}{r}\text { Curd } \\
\text { firmness }\end{array}$ \\
\hline Plasmin & $-0.01^{\mathrm{NS}}$ & $0.28^{* * *}$ & $0.5^{* * *}$ & $0.31^{* *}$ & $0.02^{\mathrm{NS}}$ & $-0.18^{\mathrm{NS}}$ \\
Plasminogen & $-0.07^{\mathrm{NS}}$ & $0.09^{\mathrm{NS}}$ & $0.26^{* *}$ & $0.5^{* * *}$ & $-0.02^{\mathrm{NS}}$ & $0.05^{\mathrm{NS}}$ \\
Plasminogen:plasmin & $-0.13^{\mathrm{NS}}$ & $-0.08^{\mathrm{NS}}$ & $0.03^{\mathrm{NS}}$ & $0.4^{* * *}$ & $-0.12^{\mathrm{NS}}$ & $0.13^{\mathrm{NS}}$ \\
\hline$* * P<0.01$. & & & & & & \\
$* * * P<0.001$. & & & & & &
\end{tabular}

in the casein content. Regardless of milk SCC, the recovery of fat and of CP increased with the advancement of lactation.

\section{DISCUSSION}

Several studies have focused on the effects of SCC and stage of lactation on milk quality and PL activity. However, little is known about the interactions between SCC and stage of lactation on ewe milk composition, enzymatic activity, and cheese-making ability.

Previous reports on the effects of SCC and stage of lactation on milk protein content are not consistent. Auldist et al. (1995) observed that milk from cows with an elevated SCC contained more total protein than milk from healthy cows, but Rogers and Mitchell (1989) did not observe any influence of SCC on this parameter. Discrepancy of results may be attributed to the fact that a number of factors are involved in the changes occurring in total protein, casein, and whey protein contents of milk with increasing SCC and the advancement of lactation, such as a reduction in the volume of milk secreted, an enhanced influx of serum proteins from the extracellular fluid into the milk (Auldist et al., 1996), and leukocyte recruitment, which can cause extensive epithelium secretory cell damage (Sevi et al., 2001). In the present trial, we did not find differences in the milk casein content, but a higher total protein content was observed in the HSCC milk when compared with the LSCC milk, which was partially due to a rise in the whey protein content.

The effects of SCC on milk fat are controversial. Kitchen (1981) and Munro et al. (1984) reported that the concentration of total fat in mastitic milk is lower than that in normal milk. Conversely, an increase in the fat content was found by Miller et al. (1983) in milk from individual mastitic cows and by Mitchell et al. (1986) in bulk milk with a high SCC compared with

Table 5. Least square means ( \pm SEM) of chemical composition of fresh cheese curd manufactured from ewe milk with low SCC (LSCC) and high SCC (HSCC) bulk milk during lactation.

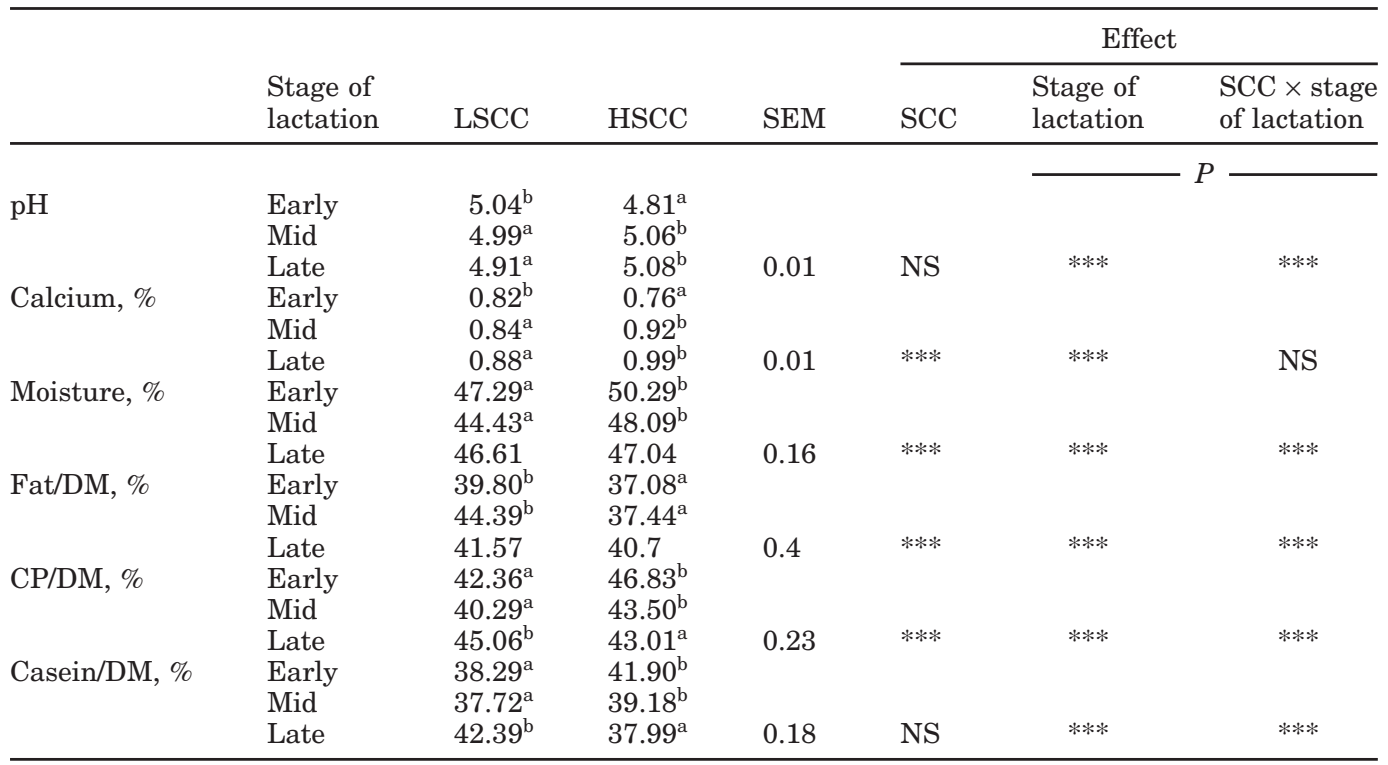

${ }^{\mathrm{a}, \mathrm{b}}$ Means within the same row followed by different letters differ at $P<0.05$.

$* * * P<0.001$ 


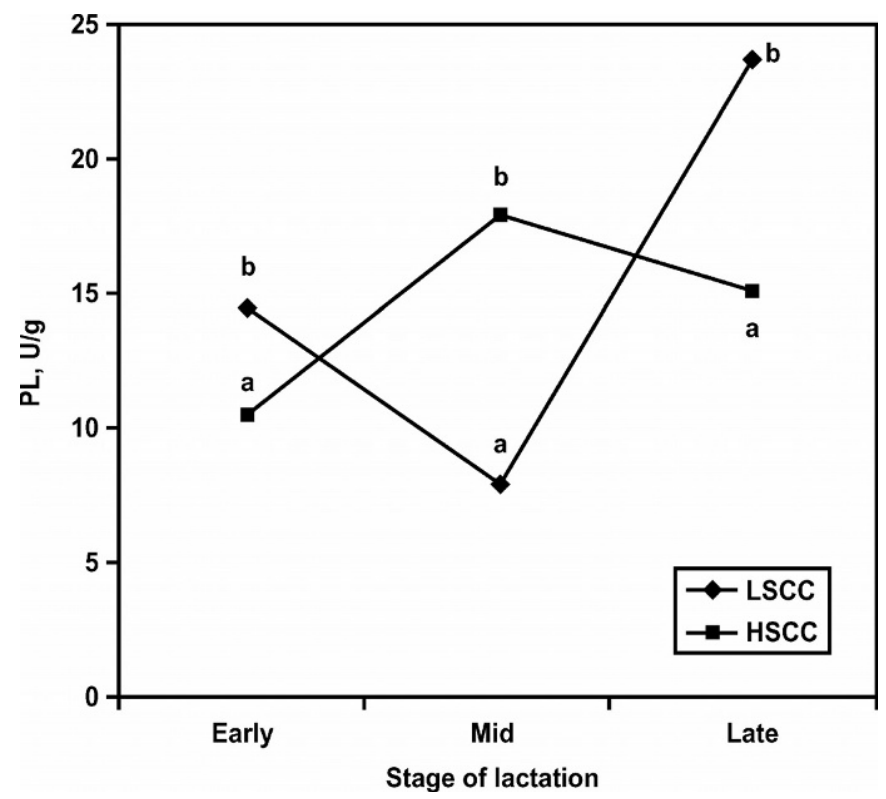

Figure 3. Plasmin (PL) activity in fresh cheese curd obtained from ewe milk with low SCC (LSCC) and high SCC (HSCC) during early, mid, and late stages of lactation. ${ }^{\mathrm{a}, \mathrm{b}}$ Means followed by different letters differ at $P<0.05$.

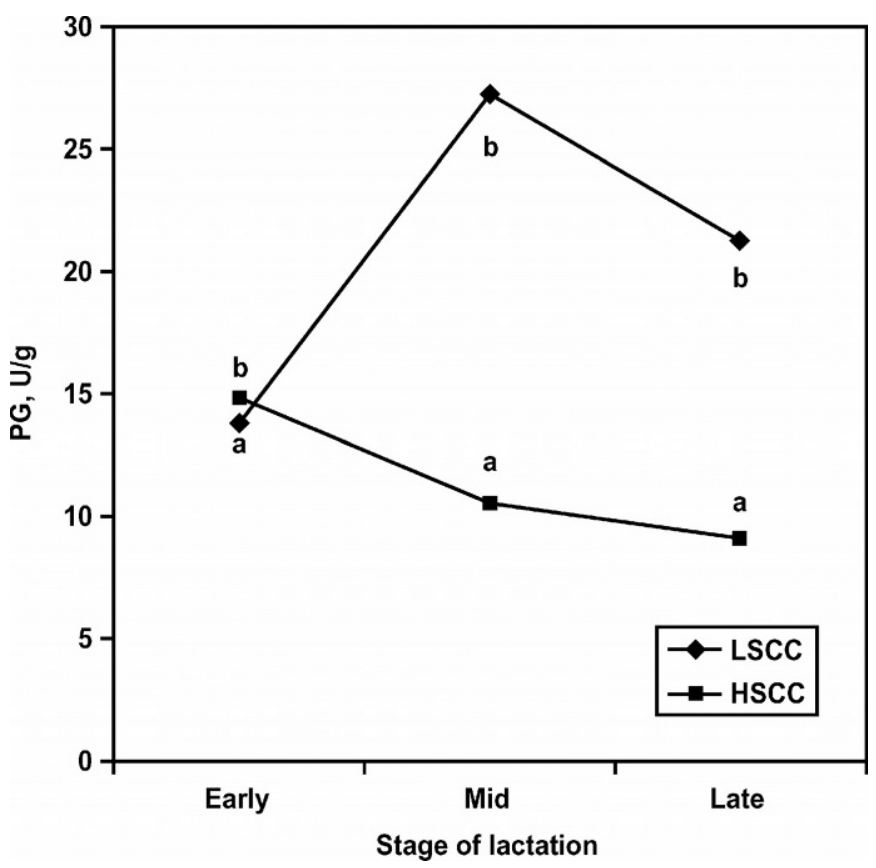

Figure 4. Plasminogen (PG) activity in fresh cheese curd obtained from ewe milk with low SCC (LSCC) and high SCC (HSCC) during early, mid, and late stages of lactation. ${ }^{\mathrm{a}, \mathrm{b}}$ Means followed by different letters differ at $P<0.05$.

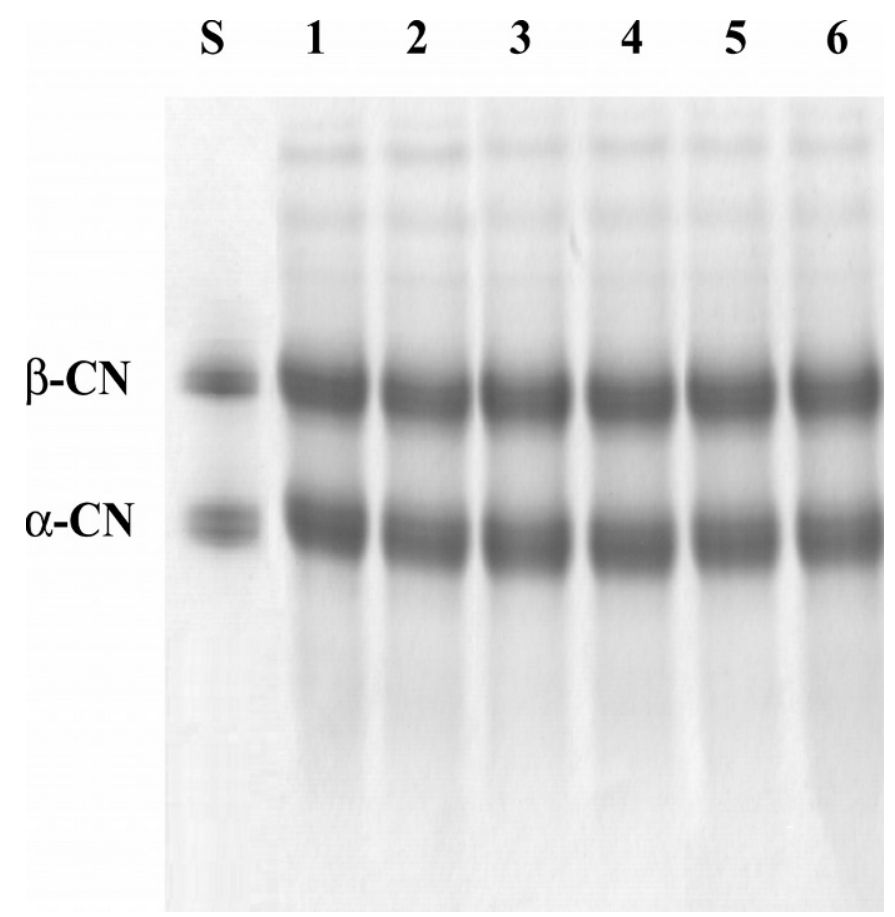

Figure 5. Urea-PAGE of plasmin activity in high SCC (HSCC) ewe milk on sodium caseinate at $\mathrm{pH} 8.0$ during lactation. Lane $\mathrm{S}$ (standard): ovine sodium caseinate purified. Lanes 1 and 2: plasmin activity at 0 and $24 \mathrm{~h}$ after incubation (early lactation). Lanes 3 and 4: plasmin activity at 0 and $24 \mathrm{~h}$ after incubation (midlactation). Lanes 5 and 6: plasmin activity at 0 and $24 \mathrm{~h}$ after incubation (late lactation).

normal milk. In the present trial, SCC did not influence the milk fat content, which increased with the advancement of lactation, probably because of the gradual reduction in the volume of milk secreted.

A lower lactose content was found in the HSCC milk throughout lactation, in agreement with previous finding (Shuster et al., 1991), which can be ascribed to a partial substitution of lactose by other osmotically active components (mainly chloride).

Polymorphonuclear leukocytes (PMNL) and lymphocytes were largely predominant in the HSCC milk, and macrophages markedly increased during lactation; these findings are consistent with previous observations (Kitchen, 1981) in cow milk. Verdi and Barbano (1991) stated that increased levels of plasmin and proteasis from PMNL and macrophages are responsible for the enhanced proteolytic activity observed in the milk produced by mastitic cows.

Several studies have documented that plasmin activity in milk increases with the rise in SCC (Politis and Ng-Kwai-Hang, 1988; Saeman et al., 1988; Politis et al., 1989) and the advancement of lactation (Politis et al., 1989; Bastian et al., 1991). In the present experiment, we found higher plasmin and PG activities in the 
Table 6. Least square means ( \pm SEM) of chemical composition of whey from cheese-making of ewe milk with low SCC (LSCC) and high SCC (HSCC) during lactation.

\begin{tabular}{|c|c|c|c|c|c|c|c|}
\hline & \multirow[b]{3}{*}{$\begin{array}{l}\text { Stage of } \\
\text { lactation }\end{array}$} & \multirow[b]{3}{*}{ LSCC } & \multirow[b]{3}{*}{ HSCC } & \multirow[b]{3}{*}{ SEM } & \multicolumn{3}{|c|}{ Effect } \\
\hline & & & & & \multirow[b]{2}{*}{ SCC } & \multicolumn{2}{|c|}{ Effect } \\
\hline & & & & & & $\begin{array}{l}\text { Stage of } \\
\text { lactation }\end{array}$ & $\begin{array}{l}\text { SCC } \times \text { stage } \\
\text { of lactation }\end{array}$ \\
\hline & & & & & & 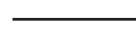 & 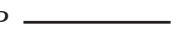 \\
\hline \multirow[t]{3}{*}{ Fat, $\%$} & Early & $1.66^{\mathrm{a}}$ & $2.32^{\mathrm{b}}$ & & & & \\
\hline & Mid & $1.71^{\mathrm{a}}$ & $3.69^{\mathrm{b}}$ & & & & \\
\hline & Late & $3.48^{\mathrm{a}}$ & $4.23^{\mathrm{b}}$ & 0.01 & $* * *$ & $* * *$ & $* * *$ \\
\hline \multirow[t]{3}{*}{ Lactose, $\%$} & Early & $4.75^{\mathrm{b}}$ & $4.46^{\mathrm{a}}$ & & & & \\
\hline & Mid & $4.25^{\mathrm{b}}$ & $3.91^{\mathrm{a}}$ & & & & \\
\hline & Late & $4.06^{\mathrm{b}}$ & $3.94^{\mathrm{a}}$ & 0.02 & $* * *$ & $* * *$ & $* * *$ \\
\hline \multirow[t]{3}{*}{$\mathrm{CP}, \%$} & Early & 1.75 & 1.72 & & & & \\
\hline & Mid & $1.52^{\mathrm{a}}$ & $1.76^{\mathrm{b}}$ & & & & \\
\hline & Late & $1.72^{\mathrm{a}}$ & $1.79^{\mathrm{b}}$ & 0.02 & $* * *$ & $* * *$ & $* * *$ \\
\hline \multirow[t]{3}{*}{ Casein, $\%$} & Early & 0.42 & 0.27 & & & & \\
\hline & Mid & 0.17 & 0.22 & & & & \\
\hline & Late & 0.26 & 0.23 & 0.11 & NS & NS & NS \\
\hline \multirow[t]{3}{*}{ Whey protein, \% } & Early & $1.43^{\mathrm{b}}$ & $1.27^{\mathrm{a}}$ & & & & \\
\hline & Mid & $1.07^{\mathrm{a}}$ & $1.25^{\mathrm{b}}$ & & & & \\
\hline & Late & $1.16^{\mathrm{a}}$ & $1.27^{\mathrm{b}}$ & 0.01 & $* * *$ & $* * *$ & $* * *$ \\
\hline
\end{tabular}

HSCC milk than in the LSCC milk regardless of stage of lactation. The higher values of the PG:PL ratio in HSCC milk was mainly dependent on the PG activity always being higher in HSCC milk than in LSCC milk, probably because of an enhanced transport of PG from blood to milk in the HSCC group. Our result suggests that the role of SCC in PG activation is more important than that played by the involution processes acting on the mammary gland at the end of lactation. In the present trial, PL activity was found to be higher in early lactation than in mid and late lactation in the HSCC group. This suggests, in agreement with the hypothesis of Zachos et al. (1992), that the increment of plasmin activity in milk, which is generally observed during the later stages of lactation, is mostly dependent on the SCC rise occurring at this time and less dependent on the mammary involution related to stage of lactation. Plasmin activity data were higher than data found for ovine milk (Chiofalo et al., 1999). This result could be at least partly explained by the higher SCC observed in our study compared with the experiment of Chiofalo et al. (1999). The very high PL activity found in the HSCC group, in line with the very high SCC observed in this group, lends support to this hypothesis.

The conversion of PG to PL is regulated by a complex network of molecular interactions between PG activators and specific PG activator inhibitors (Politis, 1996; Fantuz et al., 2001). It has been demonstrated (Verdi and Barbano, 1991; Politis et al., 1991) that milk somatic cells can convert PG to PL and that milk macrophages produce urokinase-plasminogen activators in vitro. In the present experiment, we observed that an increase in macrophage levels was associated with a lower PG activity in early and late lactation HSCC milk; on the contrary, lower values of macrophages coincided with higher values of zymogens in midlactation. Based on these results, we argued that low macrophage levels might most likely determine low levels of PG activators and, consequently, high PG activity. The highest values of macrophage cells, at the end of lactation, were associated with the lowest PG and, unpredictably, PL activities. However, milk contains several broad-specificity, plasma-derived proteinase inhibitors such as $\alpha_{2}$-antiplasmin and $\alpha_{2}$-macroglobulin (Fox, 2003). The drop in PL activity in the HSCC milk suggests the possible presence of PL inhibitors derived from blood stream caused by the weakening of the tight junctions of the mammary gland, which occurs in late lactation. This hypothesis is strengthened by the PAGE analysis of the plasmin activity ( $\mathrm{pH}$ 8.0) on sodium-caseinate, which shows a less intense proteolysis of $\beta$ - $\mathrm{CN}$ in late lactation than in midlacation and, especially, early lactation. The combined effects of SCC, macrophage levels, and permeability of the mammary epithelium to plasma-derived inhibitors may at least partly explain the highest PL levels observed in the HSCC group during early lactation. Bastian et al. (1991) showed that when SCC does not exceed $300,000 / \mathrm{mL}$, plasmin activity levels remain relatively low, and there is no correlation between milk clotting parameters and plasmin activity. In our experiment, the positive correlation between SCC and PL and PG activities confirms that the increase of so- 
matic cells leads to an increase in PL activity and in milk clotting time. Poor clotting properties are often observed with late lactation milk (Bastian and Brown, 1996). In the present trial, milk coagulation features, as well as PL activity, were markedly influenced by milk SCC and by stage of lactation, to a lesser extent.

It has been demonstrated that the changes in cow milk composition associated with a high bulk milk cell count and stage of lactation can affect the quality of cheese (Auldist et al., 1996). Cheese quality is greatly influenced by levels of peptides and amino acids resulting from proteolysis induced by indigenous enzymes of raw milk. The principle proteinase in milk is the PLPG system that strongly influences cheese ripening. In our study, PL and PG activities in fresh cheese curds had a complex evolution during lactation. In any case, PL activity was positively related to casein content in fresh cheese curds after $24 \mathrm{~h}$ of aging. Thus, it may be hypothesized that the higher the casein content, the greater the amount of $\mathrm{PG}$ activators that remain bound into the micelles and convert the PG to PL. It is well known that PG and PG activators are associated with casein micelles (Richardson, 1983). Accordingly, we observed that the highest casein concentration was associated with the highest PL activity in late lactation LSCC curds. The fact that the lowest PL activity in the HSCC curds was observed in early lactation together with the highest casein concentration may seem to be in conflict with previous considerations. However, there is evidence that plasmin is less active in low-pH cheeses (Nielsen, 2003); our results suggest that, at the beginning of cheese aging, a $\mathrm{pH}$ value of 4.8 may reduce the activation of PL enzyme despite the casein content. These findings are consistent with those of Bastian and Brown (1996), who observed that a part of PL associated with the casein, which is inactive (or inactivated) at low $\mathrm{pH}$ values, may be activated as $\mathrm{pH}$ increases during ripening.

The higher PG activity observed in the LSCC curds than in the HSCC curds during mid and late lactation suggests that cheeses manufactured from milk with a low SCC had a higher proteolytic potential than cheeses made from milk with elevated SCC.

Lawrence et al. (1993) demonstrated that $\mathrm{pH}$ and calcium content of cheese are interdependent and influenced by a variety of parameters during cheese-making. In the present study, we found that calcium levels matched with $\mathrm{pH}$ values in fresh curd cheese $24 \mathrm{~h}$ after production. This may be ascribed to the fact that high $\mathrm{pH}$ values at draining enhance the retention of minerals, mainly calcium, in the cheese curd.

On the whole, SCC content influenced the fresh cheese curd quality in terms of moisture and fat content. The LSCC milk improved the quality of Canestrato pugliese cheese through a reduction in the moisture content and an increase in the fat content with an expected improvement of its sensory attributes during ripening. Data on whey composition showed a higher ability of the casein matrix to include fat globules in the LSCC curd than in the HSCC curd.

\section{CONCLUSIONS}

The enzymatic activity in ewe milk and fresh cheese curd was markedly influenced by the milk SCC, independent from stage of lactation. Results suggest that PL activity is probably dependent on PG activators released by milk macrophages. Nevertheless, the SCC is not the only parameter for predicting PL and PG evolution in ewe milk, because of a complex network of molecular interaction between enzyme activators and inhibitors. The present experiment also demonstrates that Canestrato pugliese curds manufactured from milk with low SCC have a higher proteolytic potential than curd made from milk with elevated SCC, which can contribute to amelioration of cheese sensory attributes during ripening.

Nevertheless, further investigations are required on this topic to identify the proteolytic patterns of Comisana ewe milk to ameliorate its cheese-making efficiency.

\section{REFRENCES}

Albenzio, M., M. R. Corbo, Shakell-UR-Rehaman, P. F. Fox., M. De Angelis, A. Corsetti, A. Sevi, and M. Gobbetti. 2001. Microbiological and biochemical characteristics of Canestrato pugliese cheese made from raw milk, pasteurised milk or by heating the curd in hot whey. Int. J. Food Microbiol. 67:35-48.

Albenzio, M., L. Taibi, A. Musgo, and A. Sevi. 2002. Prevalence and etiology of subclinical mastitis in intensively managed flocks and related changes in the yield and quality of ewe milk. Small Rumin. Res. 43:219-226.

Ali, A. E., A. T. Andrews, and G. C. Cheeseman. 1980. Influence of elevated somatic cell count on casein distribution and cheesemaking. J. Dairy Res. 47:393-400. Andrews, A. T. 1983. Proteinases in normal bovine milk and their action on caseins. J. Dairy Res. 50:45-55.

Auldist, M. J., S. Coats, G. L. Rogers, and G. H. McDowell. 1995. Changes in the composition of milk from normal and mastic dairy cows during the lactation cycle. Aust. J. Exp. Agric. 35:427-436.

Auldist, M. J., S. Coats, B. J. Sutherlands, J. J. Mayes, G. H. McDowell, and L. Rogers Graeme. 1996. Effects of somatic cell count and stage of lactation on raw milk composition and the yield and quality of Cheddar cheese. J. Dairy Res. 63:269-280.

Baldi, A., G. Savoini, F. Cheli, F. Fantuz, E. Senatore, L. Bertocchi, and I. Politis. 1996. Changes in plasmin-plasminogen activator system in milk from Italian Friesian herds. Int. Dairy J. 6:1045-1053.

Bastian, E. D., and R. J. Brown. 1996 Plasmin in milk and dairy products: An update. Int. Dairy J. 6:435-457.

Bastian, E. D., R. J. Brown, and C. A. Ernstrom. 1991. Plasmin activity and milk coagulation. J. Dairy Sci. 74:3677-3685.

Blakesley, R. W., and J. A. Boezi. 1977. A new staining technique for proteins in polyacrylamide gels using coomassie brilliant blue G250. Anal. Biochem. 82:580-582. 
Chiofalo, V., A. Baldi, G. Savoini, F. Polidori, V. Dell'Orto, and I. Politis. 1999. Response of dairy ewes in late lactation to recombinant bovine somatotropin. Small Ruminant Res. 34:119-125.

Fantuz, F., F. Polidori, F. Cheli, and A. Baldi. 2001. Plasminogen activation system in goat milk and its relation with compostion and coagulation properties. J. Dairy Sci. 84:1786-1790.

Fox, P. F. 2003. Handbook of Food Enzymology. J. R. Whitaker, A. G. J. Voragen, D. W. S. Wong, ed. Marcel Dekker, Inc., New York.

Grandison, A. S., and G. D. Ford. 1986. Effects of variations in somatic cell count on the rennet coagulation properties of milk and on the yield, composition and quality of Cheddar cheese. J. Dairy Res. 53:645-655.

Grufferty, M. B., and P. F. Fox. 1988. Factors affecting the release of plasmin activity from casein micelles. N.Z. Dairy Sci. Technol. 23:153-163

Gripon, J. C., M. J. Desmazeaud, D. Le Bars, and J. L. Bergere. 1975. Etude du role des micro-organismens et des enzymes au cours de la maturation des fromages. Lait 548:502-515.

International Dairy Federation. 1970. Determination of dry matter content in whey cheese. Standard No. 58. FIL-IDF, Brussels, Belgium.

International Dairy Federation. 1989. Determination of pH. Standard No. 115A. FIL-IDF, Brussels, Belgium.

International Dairy Federation. 1992. Determination of total calcium content. Standard No. 36A. FIL-IDF, Brussels, Belgium.

International Dairy Federation. 1993. Determination of nitrogen content. Standard No. 20B. FIL-IDF, Brussels, Belgium.

International Dairy Federation. 1995. Enumeration of somatic cells. Standard No. 148A. FIL-IDF, Brussels, Belgium.

Kelly, A. L., and P. L. H. McSweeney. 2002. Indigenous proteinases in milk. Adv. Dairy Chem. 1:494-519.

Kelly, A. L., D. Tiernan, C. O'Sullivan, and P. Joyce. 2000. Correlation between bovine milk somatic cell count and polymorphonuclear leukocyte level for samples of bulk milk and milk from individual cows. J. Dairy Sci. 83:300-304.

Kitchen, B. J. 1981. Reviews of the progress of dairy science: Milk compositional changes and related diagnostic tests. J. Dairy Res. 48:167-188

Korycka-Dahl, M., B. Ribadeau Dumas, N. Chene, and J. Martal. 1983. Plasmin activity in milk. J. Dairy Sci. 66:704-711.

Lawrence, R. C., J. Gilles, and L. K. Creamer. 1993. Cheddar Cheese and Related Dry-Salted Cheese Varieties. Vol. 2. P. F. Fox, ed. Chapman and Hall, London, UK.

Le Bars, D., and J. C. Gripon. 1993. Hydrolysis of $\alpha_{\mathrm{s} 1}$-casein by bovine plasmin. Lait 73:337-344.

Lucey, J. 1996. Cheesemaking from grass based seasonal milk and problems associated with late-lactation milk. J. Soc. Dairy Technol. 49:59-64.

McSweeney P. L. H., N. F. Olson, P. F. Fox, A. Healy, and P. Højrup. 1993. Proteolytic specificity of plasmin on bovine $\alpha_{\mathrm{s} 1}$-casein. Food Biotechnol. 7:143-158.

Miller, R. H., U. Emanuelsson, E. Persson, L. Brolund, J. Philipsson, and H. Funke. 1983. Relationships of milk somatic cell counts to daily milk yield and composition. Acta Agric. Scand. 33:209-233.

Mitchell, G. E., S. A. Rogers, D. B. Houlihan, V. C. Tucker, and B. J. Kitchen. 1986. The relationship between somatic cell count, composition and manufacturing properties of bulk milk. 1. Composition of farm bulk milk. Aust. J. Dairy Technol. 41:9-12.

Mulvihill, D. M., and P. F. Fox. 1977. Proteolysis of $\alpha_{\mathrm{s} 1}$-casein by chimosin: Influence of $\mathrm{pH}$ and urea. J. Dairy Res. 44:533-540.

Munro, E. L., P. A. Grieve, and B. J. Kitchen. 1984. Effects of mastitis on milk yield, milk composition, processing properties and yield and quality of milk products. Aust. J. Dairy Technol. 39:7-16.

Nielsen, S. S. 2003. Plasmin system in milk. Pages 924-934 in Encyclopedia of Dairy Sciences. Vol. 2. H. Roginski, J. W. Fuquay, P. F. Fox, ed. MPG Books Lt, Bodmin, Cornwall, UK.
O’Brien, B., W. J. Meaney, D. McDonagh, and A. Kelly. 2001. Influence of somatic cell count and storage interval on composition and processing characteristics of milk from cows in late lactation. Aust. J. Dairy Technol. 56:213-218.

O'Keeffe, A. M., J. A. Phelan, M. K. Keogh, and P. M. Kelly. 1982. Studies of milk composition and its relationship to some processing criteria. IV. Factors influencing the rennetting properties of a seasonal milk supply. Ir. J. Food Sci. Technol. 6:39-48.

Okigbo, L. M., G. H. Richardson, R. J. Brown, and C. A. Ernstrom. 1985. Casein composition of cow's milk of different chymosin coagulation properties. J. Dairy Sci. 68:1887-1892.

Pasquinelli, F. 1981. Tecniche Ematologiche. Pages 865-923 in Diagnostica e Tecniche di Laboratorio, Vol. 2. Rosini S.r.l., Firenze, Italy.

Phelan, J. A., A. M. O'Keeffe, M. K. Keogh, and P. M. Kelly. 1982. Studies of milk composition and its relationship to some processing criteria. I. Seasonal changes in compositional of Irish milk. Ir. J. Food Sci. Technol. 6:1-11.

Politis I. 1996. Plasminogen activator system: Implications for mammary cell growth and involution. J. Dairy Sci. 79:1097-1107.

Politis, I., E. Lachance, E. Block, and J. D. Turner. 1989. Plasmin and plasminogen in bovine milk: A relationship with involution. J. Dairy Sci. 72:900-906.

Politis, I., and K. F. Ng-Kwai-Hang. 1988. Association between somatic cell count and cheese-yielding capacity. J. Dairy Sci. 71:1720-1727.

Politis, I., X. Zhao, B. W. McBride, H. J. Burton, and J. D. Turner. 1991. Plasminogen activator production by bovine milk macrophages and blood monocytes. Am. J. Vet. Res. 52:1208-1213.

Richardson, B. C. 1983. The proteinases of bovine milk and the effect of pasteurization on their activity. N.Z. J. Dairy Sci. Technol. 18:233-245.

Richardson, B. C., and K. N. Pearce. 1981 The determination of plasmin in dairy products N.Z. J. Dairy Sci. Technol. 16:209-220.

Rogers, S. A., and G. E. Mitchell. 1989. The relationship between somatic cell count, composition and manufacturing properties of bulk milk. 5. Pasteurised milk and skim milk powder. Aust. J. Dairy Technol. 44:57-60.

Saeman, A. I., R. J. Verdi, D. M. Galton, and D. M. Barbano. 1988. Effects of mastitis on proteolytic activity in bovine milk. J. Dairy Sci. 71:505-512.

SAS. SAS/STAT User's Guide, Version 8.1. 1999. SAS Inst., Inc., Cary, NC.

Sevi, A., M. Albenzio, G. Annicchiarico, M. Caroprese, R. Marino, and L. Taibi. 2002. Effects of ventilation regimen on the welfare and performance of lactating ewes in summer. J. Anim. Sci. 80:2362-2372.

Sevi, A., L. Taibi, M. Albenzio, G. Annicchiarico, and A. Muscio. 2001. Airspace effects on the yield and quality of ewe milk. J. Dairy Sci. 84:2632-2640.

Shuster, D. E., R. J. Harmon, J. A. Jackson, and R. W. Hemken. 1991. Suppression of milk production during endotoxin-induced mastitis. J. Dairy Sci. 74:3763-3774.

Srinivasan, M., and J. A. Lucey. 2002. Effects of added plasmin on the formation and rheological properties of rennet-induced skim milk gels. J. Dairy Sci. 5:1070-1078.

Verdi, R. J., and D. M. Barbano. 1991. Properties of proteases from milk somatic cells and blood leukocytes. J. Dairy Sci. 74:20772081.

Zachos, T., I. Politis, R. C. Gorewit, and D. M. Barbano. 1992. Effect of mastitis on plasminogen activator activity of milk somatic cells. J. Dairy Res. 59:461-467.

Zannoni, M., and S. Annibaldi. 1981. Standardization of the renneting ability of milk by formagraph. Sci. e Tecn. Lattiero-Casearia 32:79-94. 